\title{
Selected parameters of slaughter analysis in fatteners fed mixtures containing naked oat with or without the addition of synthetic zeolite
}

\author{
M. Fabijańska, M. Bekta, J.L. Sokól and B. Bobel \\ Department of Animal Feeding and Feed Science, \\ Warsaw Agricultural University \\ Rakowiecka 26/30, 02-528 Warszawa, Poland
}

\begin{abstract}
In an experiment with 3 groups of fatteners, the effect of the Polish naked oat cultivar Akt on the chemical composition of meat and some parameters of slaughter analysis was studied. The naked oat constituted $55 \%$ of the feed mixture. Besides it, in one group, a $3 \%$ addition of synthetic zeolite, was used. Instead of oat, the control group received the same quantity of barley. It was found that the inclusion of naked oat led to a higher fat percentage in $M$. longissimus dorsi tissue and thicker backfat layer over the shoulder. In respect to the other parameters, the differences were insignificant. The addition of zeolite decreased the loin eye arca (significantly in comparison with oat without the additive) and deteriorated meat tissue consistency as compared with the remaining groups.
\end{abstract}

KEY WORDS: naked oat, fatteners, meat quality, zeolite

\section{INTRODUCTION}

In 1997, the Polish variety of the naked oat, Akt, was introduced; it is characterized by a high energy value, comparable with maize, and by a protein level $(14 \%)$ similar to wheat but of a better quality. The high energy value of naked oat stems from its $8 \%$ fat content and only $2 \%$ content of crude fibre in dry matter (Kosieradzka, 1999; Nita, 1999). The same chemical composition allows for a higher proportion of oats in rations for fatteners but simultaneously, it may influence the quality of the slaughter product.

The aim of our experiment was to examine this influence. In one of the groups, a $3 \%$ addition of zeolite was used to study the effect of this detoxicant on the examined parameters of fattener carcasses. 


\section{MATERIAL AND METHODS}

The studies were conducted with 24 crossbred fatteners [ $q$ (Polish Large White $x$ Polish Landrace) $x \delta(D x P)]$, divided into 3 groups based on analogs, with the consideration of sex ( $4 q$ and $4 \sigma^{*}$ ). The animals were individually fed the complete feed. Naked oat meal constituted $55 \%$ of the ration for the experimental groups (II and III), while in the control group (I), barley was provided in same quantity. In addition, group II received synthetic zeolite in the amount of $3 \%$. The composition and value of the mixtures is given in Table 1. All groups had a similar level of protein, whereas the energy value of the mixtures of experimental groups was somewhat higher due to the higher energy value of the naked oat.

TABLE 1

Composition and nutritive value of the mixtures fed to pigs from 27 to $105 \mathrm{~kg}$ body weight, $\%$

\begin{tabular}{lccc}
\hline Specification & \multicolumn{3}{c}{ Group } \\
\cline { 2 - 4 } & I & II & III \\
\hline Barley meal & 55.00 & - & - \\
Wheat meal & 30.00 & 30.00 & 27.00 \\
Naked oat meal & 55.00 & 55.00 & 15.00 \\
Concentrate T' & 15.00 & 15.00 & 3.00 \\
Zeolite $^{2}$ & - & - & \\
& & & 12.38 \\
In 1 kg of mixture & 11.85 & 12.76 & 158 \\
ME MJ* & 161 & 161 & 7.25 \\
crude protein, N x $6,25 \mathrm{~g}$ & 7.10 & 7.35 & \\
lysine, g & &
\end{tabular}

* the energy value of the mixtures was calculated using the regression equations of Hoffmann and Schiemann (1980) and Miller and Kirchgessner (1983), as cited in Nutrient Requirements of Pigs (1993)

1 concentrate for fatteners

2 synthetic zeolite

The mixtures were given in two meals, mixed with water in a 1:1 ratio. During the whole fattening period, one medium-protein mixture was applied, increasing its dose every 2 weeks. Fattening was conducted from 27 to $105 \mathrm{~kg}$ body weight. After completion of fattening and slaughter of animals, loin eye area and backfat layer were measured in 4 points. Apart from this, in 4 hogs from each group, samples of $M$. longissimus dorsi were collected and the content of dry matter and crude ash (Skulmowski, 1974) and the level of crude protein and ether extract were determined using Tecator equipment. Water holding capacity was determined by the method of Wierbicki and Burrel (1962), thermal drip, by the method de- 
scribed in the paper Technology of Meat and Eggs (1977); pH was determined according to Polish Standards (1977). The organoleptic evaluation of meat was carried out according to Baryłko-Pikielna (1975).

Statistical analysis of the results was performed with Statgraphics Plus software.

\section{RESULTS AND DISCUSSION}

The fatteners in group II, receiving 55\% naked oat in the feed ration, were characterized by a somewhat higher fat content compared with the control and group III, which received the additive, zeolite (Table 2 ). Statistically significant differences were found in backfat layer only in one point-over the shoulder. Kosieradzka and Fabijańska (1999) did not find greater fatness when feeding mixtures with 30 and $98 \%$ of naked oat. The addition of zeolite in group III decreased the fatness of these animals to the level of the control group. Fatteners from group III also had the smallest loin eye area. This difference was significant in comparison with group II. Group II had a larger loin eye area than the control group (I), but this difference was not statistically significant.

TABLE 2

The results of slaughter analysis of fatteners of $105 \mathrm{~kg}$ liveweight

\begin{tabular}{lccc}
\hline \multirow{2}{*}{ Specification } & \multicolumn{3}{c}{ Group } \\
\cline { 2 - 4 } & $\mathrm{I}(\mathrm{n}=8)$ & $\mathrm{II}(\mathrm{n}=8)$ & $\mathrm{III}(\mathrm{n}=8)$ \\
\hline Backfat thickness, mm & & - & - \\
$\quad$ over the shoulder & $35.45^{\mathrm{a}}$ & $42.40^{\mathrm{b}}$ & $35.63^{\mathrm{a}}$ \\
on back & 21.60 & 25.64 & 21.01 \\
on sacrum I & 23.91 & 26.56 & 23.15 \\
on sacrum II & 16.11 & 17.63 & 14.52 \\
on sacrum III & 22.01 & 22.63 & 18.13 \\
& & & \\
Mean from 5 measurements & 23.82 & 26.93 & 22.49 \\
Loin eye area, cm & 46.86 & $48.64^{\mathrm{a}}$ & $42.09^{\mathrm{b}}$ \\
\hline
\end{tabular}

$\mathrm{a}, \mathrm{b}-\mathrm{P}<.05$

In the basic chemical composition of meat samples (Table 3), significant differences were found in crude ash content between the control (I) and experimental groups II and III. This result differs from that obtained in a study by Kosieradzka (1999) who did not find any differences in crude ash content in the muscle of fatteners fed mixtures containing from 0 to $98 \%$ naked oat. Also, the content of 
TABLE 3

Chemical composition and the results of scnsory evaluation and physicochemical properties of longissimus dorsi $\mathrm{m}$. of pigs $105 \mathrm{~kg}$ liveweight, $\%$

\begin{tabular}{lccc}
\hline \multirow{2}{*}{ Specification } & \multicolumn{2}{c}{ Group } & III $(\mathrm{n}=\mathbf{4})$ \\
\cline { 2 - 4 } & I $(\mathrm{n}=4)$ & II $(\mathrm{n}=4)$ & - \\
\hline Chemical composition, \% & & - & 23.92 \\
$\quad$ dry matter & 25.62 & 26.18 & $1.02^{\mathrm{b}}$ \\
crude ash & $0.94^{\mathrm{a}}$ & $1.06^{\mathrm{b}}$ & 23.07 \\
crude protein & 23.16 & 22.65 & $3.61^{\mathrm{B}}$ \\
ether extract & $1.00^{\wedge}$ & $4.26^{\mathrm{B}}$ & \\
& & & 0.4 \\
Water holding capacity, \% & 1.20 & 0.78 & 2.88 \\
Thermal drip, \% & 3.48 & 2.93 & 5.43 \\
pH & 5.40 & 5.40 & 4.83 \\
Colour, scores & $4.5^{\mathrm{a}} \%$ & 4.70 & 4.75 \\
Aroma, scores & 4.68 & 4.60 & 4.65 \\
Taste, scores & 4.73 & 4.68 & $4.08^{\mathrm{b}}$ \\
Consistency, scores & $4.73^{\mathrm{a}}$ & $4.65^{\mathrm{a}}$ & \\
\hline
\end{tabular}

a.b $-\mathrm{P}<.05$

$\mathrm{A}, \mathrm{B}-\mathrm{P}<.01$

ether extract was very significantly higher in the meat of animals fed the oat as compared with the control group. This is not consistent with the results obtained by Kosieradzka (1999) who did not find a higher fat content in muscle tissue when 30 or $98 \%$ naked oat was included in the diet of fatteners. On the other hand, Friend et al. (1988) even noticed a decrease in the fat content in M. longissimus dorsi as the proportion of oat increased in the mixtures.

In respect to the remaining parameters (Table 3), no significant differences were found. Also, no differences were observed between groups in relation to the majority of sensory evaluation parameters. Only the consistency of $M$. longissimus dorsi in group III was significantly worse as compared with the value of this component in the remaining groups.

The $55 \%$ proportion of oat in the mixtures for fatteners did not have any noticeable effect on the consistency or colour of fat tissue. The $3 \%$ addition of zeolite did not favourably affect the studied parameters of fatteners, which was expected based on the results of studies by authors who found more effective utilization of feed with the use of the discussed additive (Tkachev and Ustin, 1985; Wetcherek et al., after Korol, 1995). The fatteners receiving zeolite contained a similar amount of fat to the control group, whereas the loin eye area was significantly lower in comparison with the group fed the ration with an identical oat content but without zeolite. 


\section{CONCLUSIONS}

Naked oat included in a $55 \%$ proportion in diets for fatteners does not negatively affect the chemical composition of muscle tissue ( $M$. longissimus dorsi), basic parameters of slaughter analysis, organoleptic properties of the meat, or its traits as a raw material for processing as compared with the control group receiving the same quantity of barley in the mixture.

The $3 \%$ addition of zeolite did not improve the chemical composition of the meat or its organoleptic properties. On the contrary, it caused a significant decrease of loin eye area and worsened the consistency of meat tissue.

Naked oat is a good component of mixtures for fatteners

\section{REFERENCES}

Baryłko-Pikielna N., 1975. Outline of Sensory Analysis of Food (in Polish). WNT, Warszawa (Poland), pp. 273

Friend D.V., Fortin A., Poste L.M., Butler G., Kramer J.K.G., Burrows V.D., 1988. Feeding and metabolism trials and assessment of carcass and meat quality to growing finishing pigs fed naked oats (Avena nuda). Can. J. Anim. Sci. 68, 511-521

Korol W., 1995. Conservants and detoxifiers (in Polish). In: Nutritive Value of Feedstuffs. Feed Additives for Pigs. The Kielanowski Institute of Animal Physiology and Nutrition (Editor). Jabłonna (Poland), pp.109-120

Kosieradzka l., 1999. Evaluation of the possibilitics to applied Polish naked oat grain in feeding of monogastric animals (in Polish). Ph.D. Thesis, Warsaw Agricultural University Press. Warszawa (Poland)

Kosieradzka I., Fabijańska M., 1999. Polish naked oats in the intensive pig fattening. XXVIIIth Session of Animal Nutrition, Committce on Animal Sciences, Polish Academy of Sciences: Nutritional Needs of High-Productive Farm Animals. Krynica (Poland), pp. 259-262

Nita Z.T., 1999. Current situation and new directions of oats cultivation of Poland. Food 1 (18), Suppl., 186-192

Nutrient Requirements of Pigs. Nutritive Valuc of Fecdstuffs (in Polish), 1993. The Kielanowski Institute of Animal Physiology and Nutrition (Editor). Jablonna (Poland)

Polish Standard, 1977. PN-77/A-82058. Meat and Meat Products. Determination of pH in Meat

Technology of Meat and Eggs, 1997. Practical Exercises for Students in Food Technology. Warsaw Agricultural University Press. Warsz:ilwa (Poland), pp. 5-16

Skulmowski J., 1974. The Methods of Estimation of Feeds Composition and Quality (in Polish). PWRiL, Warszawa (Poland)

Tkachev E.Z.., Ustin V.V., 1985. Digestive and metabolic functions of the digestive tract of young pigs given a feed mixture containing natural zeolite (in Russian). Doklady Vaskhnil. 3, 33-35

Wierbicki E., Burrel C., 1962. Die Bestimmung der Ficischquellung als Methode zur Untersuchung der Wasserbindungskapazität von Muskelprotein mit geringen Safthaltevermogen. Fleischwirtschaft 14, 948 


\section{STRESZCZENIE}

Wybrane parametry analizy rzeźncj tuczników żywionych mieszankami $z$ udzialem owsa nagiego oraz syntetycznego zeolitu

W doświadczeniu przeprowadzonym na 3 grupach tuczników badano wpływ polskiej odmiany owsa nagiego Akt na skład chemiczny mięsa (M. longissimus dorsi) oraz niektóre parametry analizy rzeźnej. W mieszankach dla tuczników z grup II i III udział owsa wynosił 55\%, tuczniki grupy kontrolnej (I) otrzymywały zamiast owsa taką samą ilość jęczmicnia. Ponadto do mieszanki dla grupy III dodano $3 \%$ syntetycznego zeolitu.

Tusze tuczników otrzymujących owies (grupy II i III) były bardziej otłuszczone (więcej thuszczu w tkance mięsnej i grubsza słonina nad łopatką) i zawierały więcej popiołu w mięśniu najdłuższym grzbietu niż kontrolne. Pozostałe parametry nic różniły się istotnie. Tuczniki otrzymujące dodatek zeolitu miały mniejsze oko polędwicy (różnice istotne w porównaniu z grupą II) oraz gorszą konsystencję tkanki mięśniowej, lecz nie różniły się stopniem otłuszczenia w porównaniu z pozostałymi grupami. 